Arq. Bras. Med. Vet. Zootec., v.57, n.6, p.749-750, 2005

\title{
Orbital fat prolapse in a Persian cat. Case report
}

[Prolapso de gordura orbitária em um gato Persa. Relato de caso]

\author{
J.L. Laus $^{1}$, J.P. Duque Ortiz ${ }^{2}$, A.P.M. Carneiro ${ }^{2}$, C.B.S. Lisbão ${ }^{2}$ \\ ${ }^{1}$ Faculdade de Ciências Agrárias e Veterinárias - UNESP \\ Via de Acesso Prof. Paulo Donato Castellane, s/n \\ 14884-900 - Jaboticabal, SP \\ ${ }^{2}$ Estudante de Pós-graduação - UNESP - Jaboticabal, SP
}

\begin{abstract}
A two and a half-year-old female Persian cat was presented with a history of bilateral chronic ocular discharge. Epiphora bilateral mucous ocular discharge and a volume increase in bulbar conjunctiva on the dorsolateral quadrant of the right eye were noticed during routine ophthalmic examination. Ophthalmic examination and the aspiration cytology showed the presence of adipose tissue at the right eye dorsolateral quadrant indicating orbital fat prolapse.
\end{abstract}

Keywords: cat, eye, prolapse

\section{RESUMO}

Relata-se o caso de um gato da raça Persa, com dois anos e oito meses de idade, apresentando histórico de secreção ocular crônica bilateral. Ao exame oftálmico rotineiro, observou-se epífora, secreção ocular mucosidade bilateral e aumento de volume na conjuntiva bulbar, no quadrante dorsolateral, do olho direito. A punção por biopsia aspirativa da lesão do quadrante dorsolateral do olho direito demonstrou tratar-se de acúmulo de tecido adiposo, factível com prolapso de gordura orbitária.

Palavras-chave: gato, olho, prolapso

\section{INTRODUCTION}

The retrobulbar fat prolapse is uncommon in dogs (Boydell et al., 1996). This condition has also been reported in bovines (Dimison, 1993) and no reports in cat were found in the literature.

In human beings, a degenerative process of the Tenon's capsule promoting the prolapse of the orbital fat is speculated in the elderly, but the cause of this condition in animals remains unknown (Spiess and Hakason, 1998).

The clinical signs of orbital fat prolapse may be present or not, according to the size and position of the lesion (Jordan, 1993). In the canine
(Boydell et al., 1996) and bovine (Dimison, 1993) species, there are reports that the lesion is usually located on the dorsolateral quadrant of the eyes. A non-progressive increase of the conjunctival volume, which appears mobile, is observed. Enophthalmos and prolapse of the third eyelid may also be noticed (Boydell et al., 1996).

The diagnosis may be based on the physical features of the lesion (Dimison, 1993). Spiess and Hakanson (1998) advise the use of a fine needle aspiration cytology for an accurate diagnosis. The use of computerized tomography has also been suggested by Glover and Grove(1987) and Jordan (1987).

Recebido para publicação em 10 de setembro de 2004 E-mail: jllaus@fcav.unesp.br 
According to Boydell et al. (1996), the surgical treatment of the orbital fat prolapse may be applied. Dimison (1993) stated that the surgical procedure should be performed on those cases which size impairs the eye movement or if there are complications.

\section{CASUIST}

The authors report a case of a female, two and a half-year-old Persian cat, presented with a history of chronic bilateral ocular discharge. Under examination, bilateral epiphora and mucoid ocular discharge were noticed, besides a volume increase underneath the bulbar conjunctiva of the dorsolateral quadrant of the right eye (Fig. 1). The ophthalmic adnexal structures and the anterior and posterior chambers were examined using an slit lamp biomicroscope $^{1}$ and an indirect binocular ophthalmoscope $^{2}$ but no other lesions were identified. Applanation tonometry ${ }^{3}$ values for the intra-ocular pressure were within normal range. The Jones test indicated bilateral obstruction of the nasolacrimal ducts. The ultra-sound examination showed normal patterns of the periocular structures. The fine needle aspiration cytology of the mass, underneath the bulbar conjunctiva, evidenced adipose cells.

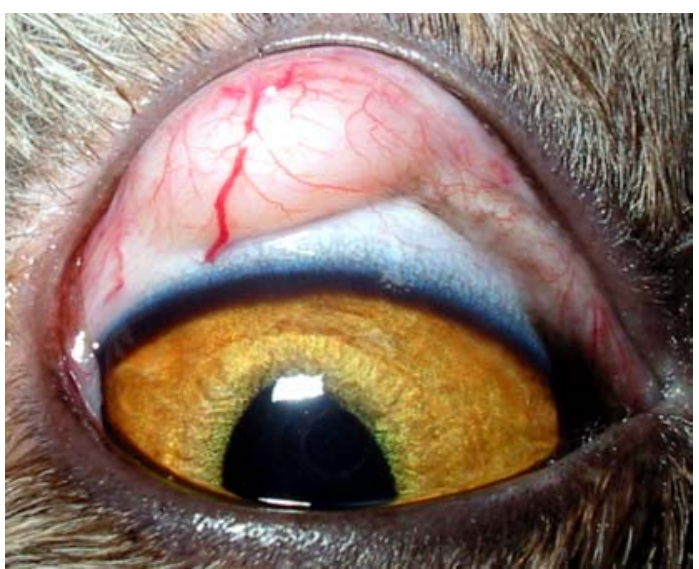

Figure 1. Cat's eye showing a tissue moss underneath the dorsal bulbar conjunctiva.

Slit Lamp SL-14 - Kowa Company Ltd.

${ }^{2}$ Oftalmoscópio binocular indireto FOH-5 Eyetec S.A

${ }^{3}$ Tono pen XL - Mentor Medical Systems.

\section{DISCUSSION}

The absence of discomfort in this patient was similar to that reported by Spiess and Hakanso (1998), who stated that this is an asymptomatic disease in the species studied. Clinical signs such as enophthalmos and prolapse of the third eyelid were not observed in this case, even though already reported by Boydell et al. (1996) in dogs.

Histopathology of the aspirated material from the lesion revealed adipose cells, as previously reported by Spiess and Hakanso (1998). Boydell et al. (1996) reported similar findings in five canine patients.

The site of the lesion (dorsolateral quadrant of the eye) was the same presented by Dimison (1993) and Boydell et al. (1996).

Due to the scarce clinical manifestations, the authors decided not to take any therapeutic measure in accordance with Dimison (1993), although Boydell et al. (1996) have suggested its surgical excision.

\section{CONCLUSIONS}

Feline is another species in which the orbital fat prolapse may occur, so it must be included in the differential diagnosis. This condition, in cats, should be confirmed by the fine needle aspiration cytology test. Therapeutic measures may be taken, even though not obligatory.

\section{REFERENCES}

BOYDEL, B.; PATERSO, S.; PIKE, R. Orbital fat prolapsein the dog. J. Small Anim. Pract., v.37, p.61-63, 1996.

DIMISON, W.G. Sialadenitis associated with periorbital disease in a dog. J. Am. Vet. Assoc., v.202, p.1983-1985, 1993.

GLOVER, A.T.; GROVE, A.S. Subconjunctival orbital flap prolapse. Ophthal. Plast. Reconstr. Surg., v.3, p.83-86, 1987.

JORDAN, D.R. Herniated orbital fat. Can. J. Ophthalmol., v.22, p.173-179, 1987.

JORDAN, D.R. Orbital fat prolapse. Arch. Ophthalmol., v.111, p.1583, 1993.

SPIESS, B.M.; HAKANSON, N.W. Diseases of the canine age. In: GELATT, K.N. Veterinary ophthalmology. Philadelphia: Lippincoot Williams \& Wilkins, 1998. cap.13, p.511-533. 
Arq. Bras. Med. Vet. Zootec., v.57, n.6, p.749-750, 2005 